\title{
Determinants of citizen engagement in rural water supply and sanitation services in Indonesia
}

\author{
Rahmi Kasri $^{1 *}$ and Paulus Wirutomo ${ }^{2}$. \\ ${ }^{1}$ Graduate School of Environmental Science, 10430 Universitas Indonesia, Indonesia \\ ${ }^{2}$ Department of Sociology, Faculty of Social and Political Sciences, 16424 Universitas Indonesia, \\ Indonesia
}

\begin{abstract}
Community-based development approach has been successful in accelerating access to rural water supply and sanitation in Indonesia. However, it suffers with criticism on its effectiveness to sustain services and to protect environment. A transformation of approach to citizen engagement is promoted to achieve better development outcomes. Through case study in four villages, this study diagnosed what define and determine citizen engagement in Indonesian rural water supply and sanitation. Determinants of citizen engagement is synthesized by using narrative thematic analysis for the qualitative data and principal component analysis for 708 household survey data. It found that citizen engagement is an interrelation of structure, culture and process elements of social life. Sustainable service of rural water supply and sanitation should be seen as enriched and restructured management cycle with citizen engagement concept. The study offers an improved service delivery cycle of rural water supply developed by Lockwood and Smith in 2011. Method of analysis and the findings of this study demonstrate the integration of sociological and environmental science perspectives. It also provides input to strengthen rural water supply and sanitation programs, especially Pamsimas and STBM, the two biggest government development programs for rural water and sanitation in Indonesia.
\end{abstract}

\section{Introduction}

Although quite successful in improving access to public goods and services, the result of a community-based approach to sustain development outcomes and to protect environment has been criticized. Some meta-evaluation studies [1-4] found that community participation and empowerment were still insufficient to effectively achieve the objective of sustainable development to ensure current and future prosperity of people and planet [5]. Rather than led by the community, the meta-evaluation studies found that sustained outcomes of development programs were mostly led by an accountable local government and/or together with community [1-4]. Accordingly, there has been a growing call in public sector to shift

\footnotetext{
* Corresponding author: rahmikasri@gmail.com
} 
the development approach from community-based to citizen engagement [6]. Citizen engagement is an interrelation between citizen and government with shared ownership and responsibility binding in a commitment to collaborate towards better development outcome [7].

One of the biggest community-based program in Indonesia is the World Bank funded Water Supply and Sanitation for Low Income Community program or Pamsimas. It was started in 2008 and aimed to provide access to water, sanitation and hygiene (WASH) to 22 million people in 27,000 villages by 2020 . Despite good progress in providing access, it has been criticized for its inability to ensure behaviour change, sustainability of services, protect environment and increase participation of women and disable groups [8, 9, 10, 11, 12). Pamsimas adopts community demand and driven (CDD) approach. It put community as the main holder of the program and government as the facilitator of community decisions. Influenced by strengthened government institutionalization in the Ministry of Health's Community-Based Total Sanitation (STBM) program, Pamsimas modified its approach from CDD to CDD with strengthened government institutional roles in 2013. By concept, the approach has begun to shift from community-based to citizen engagement.

Although widely used in social and political science, adoption of citizen engagement concept is relatively infant in the development and environment sector. Synthesizing findings from a case study in four Pamsimas villages, this paper aims to distil what determine citizen engagement in rural WASH and elaborate how adoption of this concept could lead to a better and sustain development outcome.

\section{Methods}

Citizen engagement is contextual. To understand the context, a case study was conducted in two districts with contrasting sustainability performance as seen in the Pamsimas online monitoring and information system (MIS) namely Garut District of West Java (high performance) and Agam district of West Sumatera (low performance). Two villages with good and poor sustainability performance were selected in each district, namely Silayang in Agam and Sukalaksana in Garut for good performance villages and Gumarang in Agam and Cisarua in Garut for poor performance villages. The four villages received Pamsimas intervention during the transition of CDD approach to 'citizen engagement' approach during 2008 to 2012. The management of Pamsimas piped-water is done by community through a community group namely BPSPAMS.

A mixed method data collection was applied from May 2017 to April 2018, started by structured desk study and citizen engagement model development and followed by in-depth interview $(n=32)$, focus group discussion $(n=90)$, household survey $(n=708)$ and observation to understand context and elaborate more about the preliminary developed model.

\section{Findings}

\subsection{Citizen engagement: interrelation of structure, culture and process}

Citizen engagement is an interrelation between citizen and government with shared ownership and responsibility binding in a commitment to collaborate towards better development outcome [7]. Citizen gives mandate to the government to manage and fulfil their needs and concurrently ensure accountability of the government. As a concept, citizen engagement implies an equal position and formal relation between government and citizen. 
However, such equal position does not apply to all countries. Brenschot and Klinken [13] studies in some postcolonial countries, including Indonesia, found that citizen engagement is formed through an informal interaction between citizen and government through mediated channel such as broker, reciting old values and social network. Well informed and connected citizen may increase their ability to access public services. This corresponds with Fox [14] argumentation that citizen engagement is about citizen's voice and government's willingness to listen and response. Engagement of well-informed citizen will increase public sector performance.

Engagement has three dimensions. Those are cognitive, emotional and behaviour [15]. Cognitive relates to awareness, understanding and acceptance to an object. Emotional relates to citizen and government perception on an object. Behaviour relates to interaction between citizen, government and the object. These three dimensions are shaped by the basic element of social life, namely structure, process and culture [7].

Citizen engagement requires deep understanding of the structure, culture and process elements within the context, the actor and the object of study. Structure is an element that has a coercive, imperative or constraining power to dictate human actions. In accessing rural water supply and sanitation in the case study villages, structure is formed by the nature (i.e. water resources, topography and natural disaster), program's governance (policy, budget, regulation) and social stratification. Culture is internalized value systems, norms, beliefs and traditions that form the behaviour and attitude of a community. This includes perception (i.e. about government aid and subsidy, value on water, cleanliness and comfort), gathering behaviour and respect to community leaders. Process is the dynamic of an informal or a daily community's interactions that has not been structured or cultured. This includes availability and the use of public sphere and social economic activities.

\subsection{Determinants of citizen engagement in rural water supply and sanitation services}

Both BPSPAMS' customers ( $\mathrm{n}=316)$ and non-customers (those assessing water through ground well, river, irrigation, etc., $n=392$ ) engaged in village WASH related activities. About $99 \%$ of customers and $45 \%$ of non-customers stated that they had been engaged in at least one of the following activities: community meetings, water survey, sanitation triggering activities, providing in-kind and in-cash for WASH development, paying water tariff, and monitoring community WASH behaviour. In average, the engagement of citizen in good performance villages (Samarang, 11\% and Silayang, 33\%) is higher than in poor performance villages (Cisarua, 9\% and Gumarang, 16\%).

Citizen engagement in Samarang is influenced more by supportive process and structure elements compares to culture elements. Frequent community gathering (process), compliance to village regulation, respect to the leaders and water scarcity experience due to natural disaster (structure) are more influencing than value for water or comfort (culture). In Silayang, the engagement is more influenced by nature force, service delivery governance and village regulation (structure), regular community meetings to discuss public issues (process) and comfort of having WASH facilities (culture).

In Cisarua, citizen engagement is influenced more by Pamsimas' organizational structure and regulation (structure) and aid dependent behaviour (negative culture). The engagement is tokenistic and people engaged just to meet the Pamsimas' requirement. When Pamsimas facilitators did not come regularly and management of service required customers to pay the service, people started to disengage. In Gumarang, the engagement was influenced more by the need for clean water and village regulation (structure) and aid 
seeking behaviour (negative culture). When community faced problem with regards to service delivery and local leaders and government could not help solving the problem, people started to disengage.

Using Principal Component Analysis (PCA), this study elaborate perception, attitude and behaviours factors shaping and influencing citizen engagement. Those are summarized in Table 1.

Table 1. Factors influenced citizen engagement in rural WASH.

\begin{tabular}{|c|c|c|c|}
\hline Category & Perception & Attitude & Behaviour \\
\hline Customers & $\begin{array}{l}\text { 1. WASH access } \\
\text { is mandatory. } \\
\text { 2. Improved } \\
\text { sanitation is } \\
\text { expensive. } \\
\text { 3. Water is } \\
\text { limited. } \\
\text { 4. WASH service } \\
\text { delivery } \\
\text { requires } \\
\text { supporting } \\
\text { policy, capable } \\
\text { human and } \\
\text { sufficient } \\
\text { finance. } \\
\text { Kaiser Meyer } \\
\text { Olkin (KMO) } \\
\text { test: } 0.675\end{array}$ & $\begin{array}{l}\text { 1. Engagement in } \\
\text { BPSPAMS' planning } \\
\text { and sanitation } \\
\text { triggering is important. } \\
\text { 2. BPSPAMS service } \\
\text { expansion is not yet } \\
\text { necessary. } \\
\text { 3. Engagement in water } \\
\text { service maintenance } \\
\text { and monitoring of } \\
\text { open defecation } \\
\text { behaviour is less } \\
\text { important. } \\
\text { 4. Provision of water is } \\
\text { through BPSPAM and } \\
\text { provision of sanitation } \\
\text { is by household. } \\
\text { 5. Citizen and } \\
\text { government support } \\
\text { for sanitation is } \\
\text { required. } \\
\text { KMO: } \mathbf{0 . 7 5 9}\end{array}$ & $\begin{array}{l}\text { Engagement due } \\
\text { to: } \\
\text { 1. Customary } \\
\text { involvement in } \\
\text { community } \\
\text { activities and } \\
\text { desire to be } \\
\text { heard. } \\
\text { 2. Personal interest } \\
\text { (value, interest, } \\
\text { need). } \\
\text { 3. Village and } \\
\text { Pamsimas' } \\
\text { policy and } \\
\text { requirement. } \\
\text { 4. Nature force } \\
\text { (water scarcity, } \\
\text { disaster). } \\
\text { KMO: } 0.804\end{array}$ \\
\hline $\begin{array}{l}\text { Non } \\
\text { Customers }\end{array}$ & $\begin{array}{l}\text { 1. Sources of } \\
\text { water are } \\
\text { available. } \\
\text { 2. Improved } \\
\text { sanitation is } \\
\text { expensive. } \\
\text { 3. BPSPAMS' } \\
\text { management is } \\
\text { under develop. } \\
\text { 4. WASH access } \\
\text { is mandatory. } \\
\text { KMO: } \mathbf{0 . 8 0 6}\end{array}$ & $\begin{array}{l}\text { 1. Engagement in } \\
\text { planning and sanitation } \\
\text { triggering is important. } \\
\text { 2. Joint citizen- } \\
\text { government support } \\
\text { for sanitation is } \\
\text { promoted. } \\
\text { 3. Support on } \\
\text { construction and } \\
\text { maintenance of WASH } \\
\text { facilities is needed. } \\
\text { 4. Government subsidy } \\
\text { for improved latrines is } \\
\text { required. } \\
\text { KMO: } \mathbf{0 . 8 6 8}\end{array}$ & $\begin{array}{l}\text { Engagement due } \\
\text { to: } \\
\text { 1. Experience with } \\
\text { water scarcity, } \\
\text { policy driven, } \\
\text { desire to be } \\
\text { heard. } \\
\text { 2. Unsupportive } \\
\text { personal interest } \\
\text { (value, interest, } \\
\text { need). } \\
\text { 3. Avoiding social } \\
\text { sanction. } \\
\text { 4. Natural disaster } \\
\text { experience. } \\
\text { KMO: } \mathbf{0 . 8 4 5}\end{array}$ \\
\hline
\end{tabular}




\begin{tabular}{|c|c|c|c|}
\hline Category & Perception & Attitude & Behaviour \\
\hline $\begin{array}{l}\text { Good } \\
\text { Performance } \\
\text { Village }\end{array}$ & $\begin{array}{l}\text { 1. Water is limited } \\
\text { and service } \\
\text { should be well } \\
\text { managed by } \\
\text { BPSPAMS. } \\
\text { 2. Improved } \\
\text { sanitation } \\
\text { facilities is } \\
\text { expensive. } \\
\text { 3. WASH is basic } \\
\text { need and must } \\
\text { always be } \\
\text { available. } \\
\text { KMO: } \mathbf{0 . 8 3 8}\end{array}$ & $\begin{array}{l}\text { 1. Engagement on service } \\
\text { planning, management } \\
\text { and expansion is } \\
\text { necessary. } \\
\text { 2. Engagement in } \\
\text { sanitation triggering } \\
\text { and cross subsidy from } \\
\text { the have to the poor for } \\
\text { improved latrines are } \\
\text { promoted. } \\
\text { 3. Joint monitoring for } \\
\text { OD behaviour is } \\
\text { essential. } \\
\text { KMO: } \mathbf{0 . 9 0 4}\end{array}$ & $\begin{array}{l}\text { Engagement due } \\
\text { to: } \\
\text { 1. Natural disaster } \\
\text { experience, } \\
\text { regulation, and } \\
\text { avoiding social } \\
\text { sanction. } \\
\text { 2. Internal value } \\
\text { (comfort). } \\
\text { KMO: } 0.913\end{array}$ \\
\hline $\begin{array}{l}\text { Poor } \\
\text { Performance } \\
\text { Village }\end{array}$ & 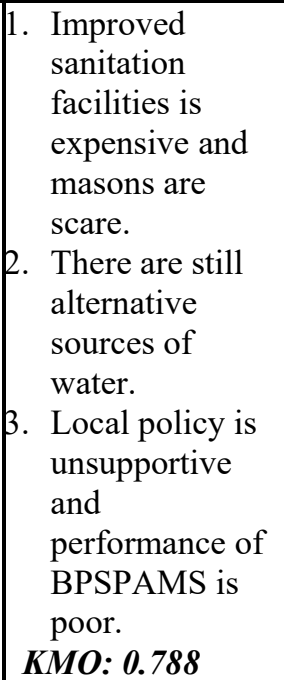 & $\begin{array}{l}\text { 1. Citizen engagement in } \\
\text { managing water } \\
\text { infrastructure and } \\
\text { monitoring OD } \\
\text { behaviour is promoted. } \\
\text { 2. Water service should } \\
\text { be provided by } \\
\text { BPSPAMS and village } \\
\text { government. } \\
\text { 3. Citizen engagement in } \\
\text { planning, construction } \\
\text { and expansion of } \\
\text { BSPAMS' service is } \\
\text { promoted. } \\
\text { KMO: } \mathbf{0 . 8 4 0}\end{array}$ & $\begin{array}{l}\text { Engagement due } \\
\text { to: } \\
\text { 1. Unsupportive } \\
\text { village policy, } \\
\text { lack of interest } \\
\text { to get service. } \\
\text { 2. Just to meet } \\
\text { program's } \\
\text { requirement. } \\
\text { 3. To follow } \\
\text { community } \\
\text { leaders. } \\
\text { 4. Avoidingsocial } \\
\text { sanction. } \\
\text { KMO: } \mathbf{0 . 7 8 5}\end{array}$ \\
\hline
\end{tabular}

Looking at all responses $(\mathrm{n}=708)$, behaviour to engage in rural WASH are divided into three principal factors: internal value $(41 \%)$, external force from community and program $(14 \%)$, and external force from the nature $(7 \%)$.

\begin{tabular}{|l|r|r|r|}
\hline \multicolumn{3}{|c|}{ Total Variance Explained } \\
\hline \multirow{3}{*}{$\begin{array}{l}\text { Initial Eigenvalues } \\
\text { nempo }\end{array}$} & Total & $\begin{array}{c}\text { \% of } \\
\text { Variance }\end{array}$ & $\begin{array}{c}\text { Cumulative } \\
\%\end{array}$ \\
\cline { 2 - 4 } & 6.115 & 40.769 & 40.769 \\
\hline 2 & 2.173 & 14.490 & 55.259 \\
\hline 3 & 1.110 & 7.401 & 62.660 \\
\hline
\end{tabular}

Component Transformation Matrix

\begin{tabular}{|l|c|c|r|}
\hline Component & \multicolumn{1}{|c|}{1} & \multicolumn{1}{|c|}{. } & \multicolumn{1}{|c|}{3} \\
\hline 1 & .575 & .565 & .592 \\
2 & - & .534 & .269 \\
& .802 & .53 & -.760 \\
\hline
\end{tabular}

Fig. 1. Factors influencing citizen engagement behaviour, all respondents. 


\subsection{Elements of citizen engagement to sustaining access to rural water and sanitation}

Transformation from community-based to citizen engagement approach is expected to result in better and more sustain development outcomes. In the context of rural WASH, sustainability will be achieved should the service management run well. It consists of: 1) strategic plan, 2) financing and budget allocation, 3) development, 4) operation and maintenance, and 5) support system [16].

This study identified activities and elements of citizen engagement needed to sustain service delivery along the service management cycle. It found that enriched service delivery cycle with citizen engagement will lead to a better sustainability of service.

1. Strategic plan; consists of setting up access target, implementation plan, post construction and cost recovery tariff. Citizen engagement in these activities is influenced by formal and informal leadership, attitude towards aid and subsidy, program induction and facilitation process, dynamic towards new regulation and behaviour, and demand for sustainable service.

2. Financing and budget allocation; consist of financing priority, budget sufficiency and alternative sources of fund. Citizen engagement on this sub-cycle is influenced by mechanism to obtain finance support from citizen and government and dynamics to perceive regulation and mechanism.

3. Development; consists of village selection for Pamsimas program, access and target achievement, budget adjustment, and facilitation process. Citizen engagement is influenced by nature force, mechanism of service delivery, response towards regulation, roles and mechanism, and monitoring.

4. Operational and maintenance (O\&M); include activities of setting up O\&M, tariff and additional number of beneficiaries. Citizen engagement is influenced by service provision (good governance), gathering and organizing behaviour, response towards regulation, mechanism and new behaviour.

5. Support system; consists of function rate, access and response towards BPSPAMS' need to improve service delivery. Citizen engagement is influenced by policy and institutional support, local structure and leadership support, behaviour change, demand creation and monitoring system.

There is a different characteristic between the citizen in good performance villages and poor performance villages. Good performance villages have an open-minded and empowered citizen, good service delivery governance, experience water scarcity due to natural disaster, supportive formal and informal policy and various community activities. Poor performance villages have aid dependency and subsidy seeking behaviour citizen, weak leadership, low trust among community members and to the government, some alternative sources of water, tend to reject new knowledge and behaviour and seldom convene community gathering.

Using NVIVO to map qualitative responses on the basic elements of social life that influence citizen engagement in rural WASH, this study found different characteristics between good and poor performance villages. Citizen engagement in good performance villages are more influenced by process, culture and structure elements while in poor performance villages, they were more influenced by structure, culture and process elements.

Besides firmed structure, culture and process elements, there are some elements in between, namely structured culture, structured process, processed structured, processed culture, cultured structure and cultured process. About $52 \%$ of qualitative responses in good 
performance villages are in this category with $24 \%$ of processed structure and more equally divided composition compared to the poor performance villages. In poor performance villages, about $48 \%$ of responses are in this category with $27 \%$ of process structure, $11 \%$ of structured process and smaller portion of the others. Bigger room for process and culture development tend to enable better citizen engagement and more sustainable services.

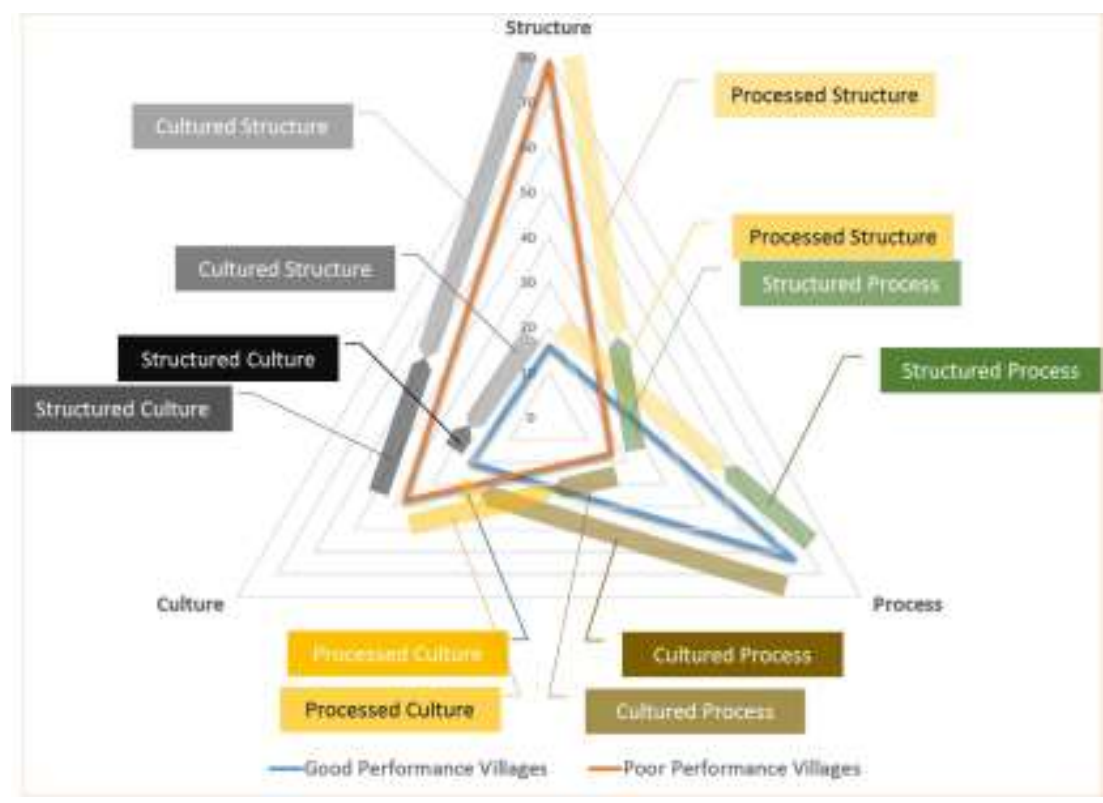

Fig. 2. Proportion of citizen engagement elements in rural water supply and sanitation.

\section{Conclusion}

Citizen engagement is influenced and shaped by the basic elements of social life namely structure, culture and process. Better citizen engagement along the service delivery cycle of rural water supply and sanitation service management will lead to more sustainable service. In good performance villages, citizen engagement is more influenced by process and culture elements while in poor performance village, it is more influence by structure and culture element. Giving more room for participation and discussion will trigger more engagement of citizen and government. It will also facilitate the creation of new behaviour and culture that will lead to a more sustain services.

\section{Acknowledgement}

The writing of this article is supported by the Universitas Indonesia TADOK Grant for School of Environmental Science. Valuable inputs were provided by Dr. Setyo Sarwanto Moersidik and Prof. Haryoto Kusnoputranto from Faculty of Engineering and Faculty of Public Health of Universitas Indonesia. 


\section{References}

1. G. Mansuri and V. Rao. Localizing development: does participation work? (WB, Washington DC, 2013)

2. G. Mansuri and V. Rao. TWBO, 19, 1, 1-39 (2004).

3. A. RochaMenocal and D. Sharma. Joint evaluation of citizens, voice \& accountability (ODI, DFID, London, 2008).

4. J. Gaventa. Development research centre on citizenship, participation and accountability annual report 2005-2006 (DRC, London, 2007).

5. United Nations. Transforming our world: the 2030 agenda for sustainable development (UN, Geneva, 2015).

6. A. RochaMenocal. Citizen engagement: theories and mechanisms (WB, Washington DC, 2016).

7. R. Kasri, P. Wirutomo, H. Kusnoputranto, S.Moersidik. IJDI, 16, 3, 276-288 (2017).

8. J. Gaventa and G. Barret. WD, 40, 12, 2399-2410 (2012).

9. M. Mc.Neil. A game changer for development? Citizen engagement: history and definitions (WB, Washington DC, 2016).

10. D. Bhatnagar, A. Dewan, M. M. Torres, P. Kanungo. Water Supply and Sanitation for Low Income Communities: Indonesia (WB, Indonesia, 2000)

11. LP3ES. Independente evaluation of WSLIC-2 and Pamsimas program (LP3ES, Jakarta, 2007).

12. Puslitsosekling. Final report of social economic management of Pamsimas (MoPW, Jakarta, 2010).

13. W. Barenchot and G.V. Klinken. CS, 22, 2, 95-111 (2018).

14. J. Fox. Social accountability: what does the evidence really say? (GPSA, 2014).

15. R. Rajan (2018). Defining and measuring engagement with digital behavior change interventions: application to the SKATA mobile application for family planning in Indonesia. (JHU SPH, Baltimore, 2018)

16. H. Lockwood and S. Smits. Supporting rural water supply, moving towards a service delivery approach. (PAP Ltd, Warwickshire, 2011). 